\section{Price and trade: World No Tobacco Day 2015}

\author{
Matthew Rimmer
}

This special issue of Tobacco Control for World No Tobacco Day is focused on the theme of Price and Trade.

Last year, Dr Margaret Chan of the WHO called on countries to increase tobacco taxes to combat the tobacco epidemic. ${ }^{1}$ Chan observed that "raising taxes on tobacco is the most effective way to reduce use and save lives" (Ibid). She commented that "determined action on tobacco tax policy hits the industry where it hurts" (Ibid).

Researchers from New Zealand have modelled the implications of regular increases in tobacco taxation in the tobacco endgame. ${ }^{2}$ The researchers contend that regulator increases in tobacco taxation can play an important role in tobacco control in New Zealand. However, a wider range of strategies will be needed to meet the smoke free goal of less than $5 \%$ prevalence by 2025 . It is particularly important that the New Zealand Prime Minister John Key implement the proposal for plain packaging of tobacco products. $^{3 \mathrm{i}}$

Cigarette price levels in five Southeast Asian countries are the topic of another paper. ${ }^{4}$ The researchers contended that "countries should adopt specific excise tax structures to decrease cigarette price variation, which would minimise opportunities for smokers to 'trade down' to a cheaper brand to avoid a tax-driven price increase" (Ibid).

Researchers from Oregon studied the implications of taxing roll-your own tobacco as pipe tobacco in the USA. ${ }^{5}$ They concluded that the USA change the Federal excise tax so that roll-your-own tobacco and pipe tobacco are taxed at the same rate.

Big Tobacco has been seeking to frustrate and delay tobacco control measures through the use of international trade agreements-such as the Trans-Pacific

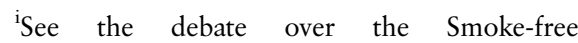
Environments (Tobacco Plain Packaging) Amendment Bill 2014 (NZ).
}

Correspondence to Dr Matthew Rimmer, Faculty of Law, Queensland University of Technology, Brisbane, QLD, Australia; drmatthewrimmer@gmail.com
Partnership, ${ }^{6}$ ii and the Trans-Atlantic Trade and Investment Partnership. The public health community is also worried about tobacco companies using investorstate dispute settlement clauses to challenge tobacco control measures-such as Australia's Plain Packaging of Tobacco Products, $^{7}$ and Uruguay's Graphic Health Warnings.

WHO Director-General Chan has noted regarding the use of investor-state dispute settlement: "One particularly disturbing trend is the use of foreign investment agreements to handcuff governments and restrict their policy space" (Ibid). Chan concluded: "Something is fundamentally wrong in this world when a corporation can challenge government policies introduced to protect the public from a product that kills" (Ibid).

In this special collection, Australian researchers consider these issues further, surveying and mapping a dozen different legal responses to protect governments' regulatory autonomy. ${ }^{8}$ They recommend that "parties take a comprehensive approach, combining provisions that minimise the potential costs of litigation with provisions that increase the likelihood of a state successfully defending tobacco control measures in such litigation" (Ibid).

In another paper, the complexities of tobacco control and trade liberalisation are analysed. ${ }^{9}$ The authors asserting that "the public health community must target efforts toward the largest, most pressing and potentially problematic substantive problems" (Ibid). In particular, they highlight the investor-state dispute settlement disputes mentioned above.

The tobacco industry has alleged that tobacco control measures such as plain packaging of tobacco products will harm business and increase illicit trade. A number of articles in this special edition of Tobacco Control deconstruct such claims. UK researchers examine the claims made by transnational tobacco companies (TTCs) to the UK consultation on plain packaging of tobacco products, ${ }^{10}$ demonstrating that the

${ }^{i i}$ See also Mitchell A, Voon T, ed. The global tobacco epidemic and the law. Cheltenham (UK) and Northampton (Mass.): Edward Elgar, 2014. tobacco companies have cited no independent, peer-reviewed evidence to support their claims, "providing further evidence that TTCs exaggerate the threat of illicit tobacco and the negative economic consequences of policy as part of a deliberate strategy to ward off regulation" (Ibid). Similarly, in an empirical analysis, another team of researchers suggest that the tobacco industry has inflated estimates of illicit cigarette consumption in Asia. ${ }^{11}$ South African economic researchers report similar findings highlighting the tobacco industry's incredible claims about the size of the illicit cigarette market in South Africa. ${ }^{12}$ They conclude, "By rewriting history about the magnitude of the illicit market, [the tobacco industry] has again shown itself as an untrustworthy source of information" (Ibid).

Philanthropists Mike Bloomberg and Bill Gates recently launched a joint legal fund to assist developing countries in legal battles with the tobacco industry over trade and investment. The Anti-Tobacco Trade Litigation Fund aims "to combat the tobacco industry's use of international trade agreements to threaten and prevent countries from passing strong tobaccocontrol laws". ${ }^{13}$ Clearly, as papers in this issue show, such support is needed.

World No Tobacco Day 2015 underlines the need to defend such public health initiatives from legal attacks by TTCs under trade agreements, investor clauses and outlandish intellectual property claims. The Anti-Tobacco Trade Litigation Fund is a welcome safeguard for such public health measures.

Competing interests None declared.

Provenance and peer review Commissioned; internally peer reviewed.

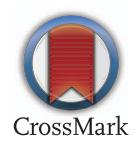

To cite Rimmer M. Tob Control 2015;24:e123-e124.

Tob Control 2015;24:e123-e124.

doi:10.1136/tobaccocontrol-2015-052450

\section{REFERENCES}

1 Chan M. WHO Calls for Higher Tobacco Taxes to Save More Lives. World Health Organization, Press Release, 27 May 2014. http://www.who.int/ mediacentre/news/releases/2014/no-tobacco-day/en/

2 Cobiac L, Ikeda T, Nghiem N, et al. Modelling the implications of regular increases in tobacco taxation in the tobacco endgame. Tob Control 2015;24:e154-60.

3 New Zealand Ministry of Health, 'Plain Packaging'. http://www.health.govt.nz/our-work/preventativehealth-wellness/tobacco-control/plain-packaging.

4 Liber A, Ross H, Ratanachena S, et al. Cigarette price level and variation in five Southeast Asian countries. Tob Control 2015;24:e137-41.

5 Tynan M, Morris D, Weston T. Continued implications of taxing roll-your-own tobacco as pipe tobacco in the United States. Tob Control 2015;24:e125-7. 


\section{Editorial}

6 Rimmer M. Plain packaging for the pacific rim: the trans-pacific partnership and tobacco control. In: Voon T, ed. Trade liberalisation and international co-operation: a legal analysis of the trans-pacific partnership agreement. Cheltenham, UK and Northampton (Mass.): Edward Elgar, 2013:75-105.

7 Chapman S, Freeman B. Removing the Emperor's clothes: Australia and tobacco plain packaging. Sydney: Sydney University Press, 2014.

8 Mitchell A. Protecting the autonomy of states to enact tobacco control measures under trade and investment agreements. Tob Control 2015;24:e147-53.
9 Drope J, Chavez JJ. Complexities at the intersection of tobacco control and trade liberalization: evidence from Southeast Asia. Tob Control 2015;24:e128-36.

10 Evans-Reeves K, Hatchard J, Gilmore A. 'It will harm business and increase illicit trade': an evaluation of the relevance, quality and transparency of evidence submitted by transnational tobacco companies to the UK consultation on standardised packaging 2012. Tob Control 2015;24:e168-77.

11 Chen J, McGhee S, Townsend J, et al. Did the tobacco industry inflate estimates of illicit cigarette consumption in Asia? An empirical analysis. Tob Control 2015;24:e161-7.

12 Van Walbeek C, Shai L. Are the tobacco industry's claims about the size of the illicit cigarette market credible? The case of South Africa. Tob Control 2015;24:e142-6.

13 Bloomberg Philanthropies and the Bill and Melinda Gates Foundation, Bloomberg Philanthropies and the Bill and Melinda Gates Foundation Launch Anti-Tobacco trade Litigation Fund, Press Release, 18 March 2015. http://www.bloomberg.org/press/ releases/bloomberg-philanthropies-bill-melinda-gatesfoundation-launch-anti-tobacco-trade-litigation-fund/ 